\title{
STUDI FENOMENOLOGI \\ PENGALAMAN PASIEN DALAM PENANGANAN PATAH TULANG DENGAN BA'URUT
}

\author{
Aulia Rachman', Bahrul Ilmi' ${ }^{2}$, Yeni Mulyani ${ }^{3}$ \\ ${ }^{1}$ Mahasiswa Pascasarjana Universitas Muhammadiyah Banjarmasin 70114 Indonesia \\ ${ }^{2,3}$ Staff Dosen Politeknik Kesehatan Banjarmasin, 70714, Indonesia \\ Email : auliarachman04@gmail.com
}

\begin{abstract}
ABSTRAK
Latar Belakang : Berbagai macam jenis penatalaksanaan untuk patah tulang dapat ditemukan di masyarakat, dan masyarakat bebas memilih sendiri tindakan mana yang mereka yakini. Data Riskesdes 2018 menunjukkan bahwa masyarakat Kalimantan Selatan yang memilih pemanfaatan pelayanan kesehatan tradisional seperti pijat urut/baurut dan penyehat tradisional dibandingnya pengobatan medis masih sangat tinggi. Penelitian ini bertujuan untuk mengekplorasi pengalaman pasien dalam penanganan patah tulang dengan Ba'urut di Kalimantan Selatan.

Metode : Desain penelitian kualitatif dengan pendekatan fenomenologi. Pengumpulan data menggunakan wawancara mendalam terhadap 5 (lima) partisipan yang diambil dengan teknis purposive sampling berdasarkan kriteria inklusi. Analisis data menggunakan teknik analisis data kualitatif Cresswel.

Hasil penelitian : Penelitian ini menemukan 4 (empat) tema utama yaitu (1) Alasan ekonomi dan kemudahan pelayanan, (2) Proses baurut, (3) Dampak fisik setelah baurut, (4) Respon psikologis dari hasil pengobatan baurut.

Kesimpulan: Adanya berbagai macam faktor yang mempengaruhi dari pemilihan pengobatan baurut ini perlu diperhatikan terutama adanya peran serta petugas kesehatan yang mengedukasi sebagai care giver dalam memberikan pilihan dalam mengambil keputusan pengobatan yang akan diambil dengan memperhatikan adanya gejala sisa yang akan ditimbulkan dari baurut.
\end{abstract}

Kata kunci : pengalaman, penanganan patah tulang, Baurut 


\section{PENDAHULUAN}

Pengobatan tradisional adalah suatu pelayanan jasa yang berkembang di masyarakat dengan pola hubungan antarwarga yang didasarkan pada kepercayaan masyarakat dengan budaya daerah dalam mengambil keputusan berdasarkan landasan timbal balik dan interpersonal. Budaya yang melekat pada individu akan memberikan pengaruh bagaimana individu itu berpikir dan bertindak serta dalam mengambil keputusan (Utami, 2015).

Sebuah studi terkait pemilihan pengobatan tradisional di United States, menunjukkan pada pasien dengan masalah muskuloskeletal yang mengunjungi ahli tulang sebesar $23 \%$ dalam kurun waktu satu tahun terakhir yang menggunakan pengobatan tradisional (WHO Traditional Medicine Strategy, 2013). Prevalensi global penggunaan pengobatan tradisional atau alternatif adalah 9,8\%-76,0\% sangat bervariasi dari satu negara dengan negara lain, misalnya $38 \%$ di Amerika Serikat, 51,8\% Britania Raya, 68,9\% Australia dan $74,8 \%$ Korea selatan. Jenis pengobatan alternatif yang digunakan dengan pijat. (Bahall \& Legall, 2017).

Keterikatan antara budaya dan kesehatan saling keterkaitan dalam kehidupan sehari hari. Hal ini sesuai dengan Leininger dalam Alligood (2017) Budaya merupakan struktur yang sangat penting dalam memetakan keserasian hubungan kehidupan masyarakat. Budaya berhubungan dengan perawatan, kesehatan, penyakit, dan lingkungan keseluruhan yang kompleks, yang mencakup pengetahuan, kepercayaan, seni, moral, hukum, adat, dan setiap kemampuan dan kebiasaan lainnya yang diperoleh manusia sebagai anggota masyarakat.

Leininger dalam Alligood 2017 mengatakan bahwa budaya mempunyai pengaruh yang luas terhadap kehidupan suatu keluarga. Hal ini dapat memberikan pengaruh terhadap perilaku kesehatan keluarga yang meliputi kebiasaan hidup sehari-hari, pekerjaan, pergaulan sosial, praktik kesehatan, ekspresi perasaan dalam menentukan pilihan pengobatan tradisional.

Riskesdes (2018), 54,1\% masyarakat Kalimantan Selatan memilih pemanfaatan pelayanan kesehatan tradisional, 83,3\% masyarakat Kalimantan Selatan memilih pengobatan dengan keterampilan tanpa alat termasuk pijat urut/baurut, serta memilih penyehat tradisional $98,9 \%$. Berdasarkan data di atas menunjukan bahwa pengobatan tradisional masih banyak mendapat tempat disamping pengobatan modern dan masih digunakan oleh masyarakat di Kalimantan Selatan.

Beberapa dari pengalaman pasien dalam sebuah alasan dalam mengambil keputusan seseorang memilih pengobatan tradisional menangani patah tulang dengan Baurut. Alasan partisipan untuk memilih pengobatan tradisional karena adanya pengaruh sosial budaya, pengalaman yang melingkupi perilaku seseorang pada saat mereka mencari pengobatan, antara lain faktor sosial budaya yaitu mengenai kecocokan dan kepercayaan pasien (sugesti) serta dari segi ekonomi mengenai mahalnya biaya pengobatan medis. Adanya kemungkinan komplikasi yang dialami pada patah tulang akan terjadi, dari patahan tulang yang mengalami perbedaaan tekanan dalam sumsung tulang akan muncul gejala sisa.

\section{METODE PENELITIAN}

Penelitian ini di lakukan di Kalimantan selatan yang terdiri dari Kabupaten Banjar, Kabupaten Tanah Laut, Banjarmasin pada bulan November 2019 sampai Januari 2020, 
dengan menggunakan metode kualitatif dengan pendekatan fenomenologi deskriptif. Pengumpulan data dilakukan menggunakan teknik wawancara mendalam terhadap 5 (lima) partisipan yang mempunyai pengalaman patah tulang menggunakan pertolongan dengan baurut yang telah dipilih dengan menggunakan teknik purposive sampling. Kriteri inklusi pasien dengan riwayat patah tulang dengan baurut, pengalaman baurut tidak lebih dari 3 tahun. Seluruh partisipan diberikan pertanyaan yang sama. Data hasil wawancara dianalisis menggunakan teknik analisis data Cresswel.

\section{HASIL PENELITIAN}

Terdapat enam tema yang terindentifikasi dari hasil analisa data kualitatif yang dikumpulkan melalui wawancara mendalam terdapat 5 partisipan. Tema utama yang memaparkan berbagai pengalaman partisipan dalam penanganan patah tulang dengan Baurut di Kalimantan Selatan. Tema tersebut yaitu Alasan ekonomi dan kemudahan pelayanan, Proses baurut, Dampak fisik setelah baurut, Respon psikologis dari hasil pengobatan baurut.

Tema yang dihasilkan dalam penelitian ini dibahas terpisah untuk menguraikan berbagai pengalaman partisipan dalam penanganan patah tulang dengan menggunakan Baurut. Tema yang muncul saling berhubungan satu sama lain untuk menjelaskan suatu esensi pengalaman partisipan dalam penanganan patah tulang dengan Baurut.

\section{Alasan ekonomi dan kemudahan pelayanan}

Tema ini menggambarkan tentang alasan partisipan dalam memilih penanganan patah tulang dengan Baurut. Tema ini terbentuk dari beberapa ungkapan partisipan yang menyatakan bahwa alasan ini yang mempengaruhi dalam menentukan untuk pengobatan yang digunakan. Partisipan yang memilih pengobatan Baurut ini sebagai alasannya yang diungkapkan oleh 2 partisipan ini yang menyatakan dalam kutipan berikut ini :

"...amun dibandingkan dengan medis larang banar...(Pl)”

"...bila dibandingkan dengan medis lebih mahal...(P1)

"...amun beurut ne lakas banar tuntung...(P2)"

“...bila baurut ini cepat selesai...(P2)

\section{Proses pelaksanaan Baurut}

Tema ini menggambarkan tentang proses/metode Baurut. Tema ini muncul dari sub pertanyaan bagaimana cara metode Baurut yang dilakukan oleh paurutan. Proses ini di ungkapkan oleh partisipan yang menyatakan dalam kutipan berikut ini :

“...lalu kaya sidin tarik kaya arah menjauh searah kada bolak balik..."(P1)

"...lalu seperti ditarik beliau kearah menjauh searah tidak bolak balik...(P1)

"...baurutnya tu ditarik searah kaya membujurakan...(P3)

"...Baurut itu ditarik searah seperti membetulkan..."

\section{Dampak fisik setelah Baurut}

Tema ini menggambarkan dampak fisik yang timbul setelah dilakukan penanganan Baurut, dampak fisik yang terjadi pada partisipan ada berbagai macam yang dialami, diantaranya terjadi berbagai macam ungkapan 2 partisipan dalam ungkapan berikut ini :

“... ada rasa marenyot di batis nang patah...(P4)”

"...ada rasa nyeri di kaki yang patah...(P4)

"...posisi ne model miring...(P3)"

“...posisinya seperti miring...(P3) 


\section{Respons psikologi dari hasil pengobatan Baurut}

Tema ini menggambarkan respon psikologis dari hasil pengobatan beurut, dari berbagai macam partisipan mengalami respon psikologis yang berbeda beda. Tema ini muncul dari pertanyaan mengenai perasaan pada saat menggunakan Baurut. perasaan ini bisa berpengaruh kepada aktivitas yang akan dijalani partisipan setiap harinya. Respons psikologis yang muncul antara lain:

"...aku banarae nang tekutan rasa waswas...(P2)"

"...Aku saja yang takut dan rasa waswas...(P2)

"...nang dihindari ne bukah
banarae...(P5)..."
"...Yang dihindari lari saja...(P5)

\section{PEMBAHASAN}

\section{Alasan ekonomi dan kemudahan pelayanan}

Tema pertama pada penelitian ini menggambarkan alasan dalam memilih pengobatan beurut yang dilakukan seluruh partisipan. Alasan memilih pengobatan baurut ini dipengaruhi beberapa faktor dalam penelitian ini terutama karena alasan ekonomi. Ketika seseorang menghadapi masalah-masalah dalam hidup diantaranya masalah kesehatan (sakit) maka seseorang tersebut berusaha untuk mencari obat untuk pengobatan untuk menyembuhkan penyakit tersebut. Sebagian ada yang memilih pengobatan modern dan pengobatan tradisional. Salah satu faktor yang menentukan pemilihan cara pengobatan adalah jumlah pendapatan. Orang yang memiliki pendapatan tinggi cenderung akan memilih fasilitas pengobatan modern, sedangkan orang yang memiliki pendapatan yang kurang akan lebih memilih pengobatan tradisional (Soenanto, 2006 dalam Juwita,E 2013).
Penelitian ini sejalan dengan penelitian yang dilakukan oleh Erni Juwita (2013) yang menyatakan bahwa pendapatan (ekonomi) mempengaruhi pengunaan pelayanan kesehatan. Dalam penelitian ini ada beberapa alasan yang menyebabkan pengobatan tradisional menjadi pilihan utama untuk menentukan pilihan diantaranya adalah pola pelayanan dan biaya pengobatan yang murah dan bisa dijangkau oleh lapisan masyarakat menengah kebawah.

Penelitian ini bahwa faktor ekonomi merupakan salah satu faktor yang mempunyai peranan besar dalam kehidupan pasien dengan patah tulang yang menggunakan pengobatan tradisional yaitu baurut, keadaan ekonomi dapat menentukan suatu keputusan dalam menentukan pengobatan yang sesuai dengan kemampuanya. Hal ini sangat berpengaruh terhadapa resiko yang di alami apabila kondisi kesehatan mengalami kecacatan atau tidak berfungsi secara maksimal.

Status ekonomi atau kondisi ekonomi dari keluarga turut memengaruhi keputusan dalam pemenuhan informasi dan keluarga dalam menjalani pengobatan baik memilih medis atau tradisional. Menurut Sitomorang (2014) menyatakan bahwa status informasi yang jelas akan menentukan keputusan seseorang, berakibat baik atau tidak dari keputusan yang ditimbulkan. Dalam hal ini tidak baik akan menimbulkan efek samping atau gejala sisa (kecacatan).

Lebih lanjut Potter dan Perry (2010) mengatakan bahwa pendapatan merupakan salah satu faktor yang mempengaruhi tingkat wawasan pengetahuan masyarakat mengenai sanitasi, lingkungan, informasi dan perumahan. Kemampuan anggaran rumah tangga juga mempengaruhi kesepatan untuk meminta pertolongan 
apabila salah satu anggota keluarga sakit. Status ekonomi dapat mempengaruhi tingkat kesehatan seseorang dengan cara meningkatkan resiko terjadinya penyakit dan mempengaruhi cara bagaimana atau dimana seseorang masuk kedalam system pelayanan kesehatan. penerimaan seseorang terhadap pengobatan yang bertujuan untuk memelihara atau meningkatkan kesehatannya juga dipengaruhi oleh status ekonomi.

Mubarak dan chayatin (2009) juga mengatakan bahwa status ekonomi atau tingkat penghasilan keluarga akan mempengaruhi cara hidup/gaya hidup seseorang dan cara memperoleh pelayanan kesehatan apabila ada anggota keluarga yang mengalami sakit. Seseorang yang berasal dari keluarga dengan penghasilan tinggi cenderung lebih mudah dalam memperoleh pelayanan dan fasilitas kesehatan, dibandingkan dengan orang berasal dari keluarga dengan penghasilan rendah. Keluarga dengan penghasilan tinggi cenderung mendapat kesempatan lebih tinggi untuk mendapatkan pengetahuan dan informasi tentang arti kesehatan dan manfaat dari pelayanan.

Pengobatan tradisional merupakan bagian yang integral dari kebudayaan, karena konsep tentang kondisi sakit dan cara pengobatannya itu tidak berdiri sendiri, tetapi terintegrasi dengan kebudayaan lainnya. Masih digunakannya cara pengobatan tradisional dikalangan masyarakat pendukungnya disebabkan fungsinya mampu memenuhi kebutuhan yang berhubungan dengan kesehatan. Dalam pengobatan tradisional ada mekanisme dan syarat tertentu yang harus dipatuhi, sehingga ia merupakan ciri dari kebudayaan masyarakat yang bersangkutan yang dapat dikaitkan dengan pelayanan kesehatan modern (Ideham,2007).

Dalam hal kemudahan dalam mendapatkan pelayan yang diinginkan dari setiap orang dalam mencapai pengobatan yang terjangkau dan lebih mudah, murah itu yang ingin diharapkan dari masyarakat saat ini, hal ini lebih tergambar dari peran tenaga kesehatan dalam tercukupinya fasilitas pelayanan kesehatan yang mudah dalam memberikan pelayanan tanpa adanya hambatan, adanya Kolaborasi profesional kesehatan, pada dasarnya dibutuhkan untuk menjangkau pelayanan kesehatan khususnya di daerah dimana adanya keterbatasan fasilitas kesehatan (Engel \& Prentice, 2013). Kolaborasi merupakan komponen penting tercapainya keberhasilan dalam pelayanan kesehatan (Prentice et al, 2015). Kolaborasi membuat pelayanan kesehatan dapat dilakukan dengan cepat, tepat serta optimal (Martinmisener et al, 2012). Melewati kolaborasi pengalaman dan keahlian dapat disatukan yang kemudian akan mempengaruhi perkembangan pelayanan perawatan (Murthy, 2016). Proses kolaborasi harus didasari kepercayaan dan ketulusan sehingga mampu menciptakan pelayanan kesehatan yang memuaskan pengguna, termasuk dalam kolaborasi dengan tradisional (Clancy \& Svensson, 2010).

\section{Proses Baurut}

Tema ketiga pada penelitian ini menggambarkan proses/metode baurut yang dilakukan paurutan. Dari beberapa partisipan mengungkapkan proses yang sama pada penelitian ini. Partisipan yakin mempercayai baurut berasal dari turun temurun dan dipercaya memberikan kesembuhan pada orang dewasa. Pengobatan merupakan suatu usaha untuk melakukan penyembuhan terhadap suatu penyakit. Umumnya dilakukan orang yang ahli dalam menanganinya seperti tenaga medis (dokter) atau penyembuhan (dukun) dimana kedua profesi ini memiliki cara 
tersendiri dalam melakukan penyembuhan penyakit seseorang (setyoningsih \& Artaria, 2016).

Seluruh partisipan bisa menjelaskan tentang proses/metode baurut namun partisipan tidak memahami makna bacaan do'a dan cara pemijatan/peurutan yang telah dilakukan kepada parap partisipan. Sebelum paurutan melakukan proses pelaksanaan baurut, peurutan melakukan pengkajian terlebih dahulu untuk memastikan bagaimana keadaan pasienya, dimana tempat patah tulangnya dan keluhan lainnya. Hal ini sejalan dengan Notosiswoyo (2001) yang menyatakan bahwa sebelum melakukan pemijatan para ahli batra melakukan pemeriksaan/pengkajian terlebih dahulu supaya apa yang mereka lakukan tidak menimbulkan komplikasi atau dampak yang merugikan saat melakukan pengurutan.

Prinsip pengurutan yang dilakukan oleh paurutan tidak jauh beda dengan dengan pengobatan tradisional baurut lainnya yang digunakan di daerah lain. Hanya saja nama disesuaikan dengan daerah yang berbeda. Prinsip pengobatan tradisional beurut ini tidak jauh beda dengan pengobatan medis yang di lakukan dirumah sakit hanya saja pada pengobatan baurut ini terbatas pada patah tulang tertutup saja, sedangkan medis bisa mengatasi patah tulang dengan terbuka. Prinsip yang pengobatan beurut antara lain mencakup pemberian sugesti penguatan psikis, reposisi, relaksasi dan fiksasi. Sugesti dilakukan dengan cara memberikan air minum yang sudah diberi do'a do'a dan dimotivasi. Hal yang demikian ini sejalan dengan Notosiswoyo (2001) menyatakan keahlian seorang pengobatan tradisional bisa membuat pasiennya lebih percaya dan tersugesti dengan kesembuhan.

\section{Dampak fisik setelah Baurut}

Tema kedua pada penelitian ini adalah menggambarkan tentang dampak fisik dari Baurut. Menurut Kamus Besar Bahasa Indonesia online (KKBI Online)(2019) dampak merupakan pengaruh kuat yang mendatangkan akibat (baik negative maupun positif). Patah tulang dapat menyebabkan deformitas apabila tidak ditangani dengan tepat. Deformitas ini dapat terjadi apabila tulang yang mengalami kerusakan apabila penyambungannya tidak tepat. Dengan jenis deformitas antara lain ketidaksejajaran posisi tulang saat pembuhan pada saat terjadi patah tulang, abnormalitas tulang panjang atau mengalami kelainan, pertumbuhan abnormal pada tulang.

Prinsip penanganan patah tulang adalah mengembalikan posisi patahan tulang ke posisi semula (reposisi) dan mempertahankan posisi itu selama masa penyembuhan patah tulang (imobilisasi). Penatalaksanaan umum patah tulang meliputi menghilangkan rasa sakit, menghasilkan dan mempertahankan posisi yang ideal dari patah tulang, agar terjadi penyatuan tulang kembali sehingga fungsi dapat kembali seperti semula. Untuk nyeri dapat dilakukan immobilisasi (tidak menggerakan daerah patah tulang) dan dapat diberikan obat penghilang sakit. Tehnik immobilisasi dpat dilakukan dengan pembidaian atau gips, pemasangan traksi kontinu, fiksasi eksternal atau fiksasi internal (Buchol, et al. 2006).

Pemanfaata pengobatan tradisional sangat banyak diminati oleh masyarakat karena keyakinan mereka untuk tetap memilih pengobatan tersebut. Tidak sedikit masyarakat yang lebih percaya kepada pengobatan tradisional seperti baurut. Tidak sedikit pasien yang mengalami komplikasi akibat penanganan pertamanya yang tidak baik atau tidak sesuai dengan 
prinsip penanganan patah tulang yang benar. Alasan yang terbesar masyarakat yang terlambat berobat kerumah sakit adalah masalah ekonomi (Sari Ap. 2012).

\section{Respons psikologis dari hasil pengobatan Baurut}

Respon psikologis terjadi karena pengobatan berurut yang dijalani partisipan memiliki dampak terhadap perubahan fisik. Perubahan bentuk serta nyeri pada bekas patah tulang, diungkapkan partisipan mempengaruhi kondisi psikologisnya. Dampak yang tidak sesuai dengan yang diharapkan menunculkan berbagai perasaan seperti malu terhadap perubahan fisiknya, ragu terhadap pengobatan berurut serta perasaan takut patah tulang yang dialami akan kambuh berulang. Hasil berurut yang tidak sesuai dengan harapan ini menjadi sebuah stresor bagi partisipan terutama dalam melakukan aktifitas sehari-hari. Dalam beraktifitas, partisipan kerap merasa takut dan was-was patah tulang akan kembali kambuh. Rasa khawatir ini kemudian mengakibatkan partisipan membatasi pekerjaan yang biasanya dilakukan. Partisipan mulai menghindari jenis pekerjaan yang membutuhkan kekuatan fisik yang besar. Disisi lain, seringnya muncul rasa sakit dan nyeri pada bekas patahan tulang mengakibatkan partisipan memilih membatasi aktifitasnya.

Perubahan fisik serta aktifitas yang terjadi setelah pengobatan tradisional berurut dilakukan memunculkan respon psikologis seperti stres. Stuart (2016) menjelaskan bahwa stres dapat terbentuk dari sebuah kondisi yang tidak sesuai harapan. Stres ini bila dibiarkan dapat menjadi sumber stresor pada seseorang. Selain itu, studi lain menunjukan bahwa harapan yang tidak tercapai menjadi sebuah stresor utama yang dapat menimbulkan perasaan tertekan dan mempengaruhi psikologis seseorang (Lanawati, 2019).

Stresor adalah stimulus yang memiliki sifat menantang maupun mengancam serta membutuhan energi untuk mengatasinya. Stimulus ini dapat memunculkan situasi ketegangan dan stress pada individu yang mengalaminya (Stuart, 2016). Dampak fisik berurut yang tidak sesuai harapan tersebut menciptakan situasi penuh tekanan yang menjadi sumber stresor dan memiliki potensi menciptakan stres (Didymus, 2017). Stres yang dialami partisipan terkait kondisi fisik harus diatasi dengan menggunakan mekanisme koping yang adaptif. Apabila dampak fisik yang terjadi akibat pengobatan berurut dipandang sebagai sebuah tantang yang menguntungkan, maka stres akan berkurang. Stresor akan cenderung sulit diatas, apabila stressor.

\section{KESIMPULAN}

Hasil penelitian ini didapatkan dalam penanganan patah tulang pada masyarakat banjar masih banyak menggunakan pengobatan patah tulang tradisional yang banyak dikenal dengan baurut, pemilihan pengobatan ini didasarkan karena mudah dan murah dalam pengobatannya tetapi masih menimbulkan gejala sisa yaitu menimbulkan dampak secara fisik dan psikologis yang disebabkan karena penanganan yang tidak tepat. Akibat adanya gejala sisa ini menimbulkan efek samping yang permanen sehingga perlu adanya edukasi yang baik dalam penentuan pemilihan pengobatan ini, tentunya dengan memperhatikan berbagai macam faktor yaitu ekonomi, pengetahuan dalam pengobatan. Sehingga bisa mempertimbangkan antara pengobatan medis dan tradisonal. 
Bagi institusi pelayanan keperawatan dengan hasil penelitian ini menjadi dasar tentang pentingnya bagi tenaga kesehatan dalam memberikan asuhan keperawatan kepada klien patah tulang dengan memberikan edukasi promosi kesehatan pada masyarakat sehingga ada pertimbangan dalam menentukan pilihan pengobatan agar tidak salah ambil yang akan menimbulkan kecacatan atau gejala sisa.

Mensosialisasikan dipelayanan kesehatan maupun masyarakat menengah kebawah untuk menjadi pertimbangan dalam menentukan pengobatan yang sesuai, sehingga dampak negative dapat dihindari.

Meningkatkan pemaparan tentang pengobatan tradisional berdasarkan evedance based nursing practice sehingg ketika perawat berada di tengah-tengah masyarakat dapat memahami kebiasaan, budaya, perilaku dan proses hubungan sosial yang dapat mempengaruhi kondisi sehat dan sakit.

Pendidikan keperawatan hendaknya mampu membentuk menanamkan nilainilai profesionalisme keperawatan kepada mahasiswa sebagai calon perawat yang memiliki peran sangat tinggi terhadap peningkatan mutu layanan kesehatan khususnya layanan keperawatan.

\section{DAFTAR PUSTAKA}

Afiyanti, D., \& Rachmawati, I. (2014). Metodologi Penelitian Kualitatif dalam Riset Keperawatan. Jakarta: Rajawali Pers.Alligood, M. 2017. Pakar Teori Keperawatan dan Karya Mereka, Edisi 8 Volume 1. Singapura. Elsevier.

Bahall, M., \& Legall, G. (2017). Knowledge, attitudes, and practices among health care providers regarding complementary and alternative medicine in Trinidad and Tobago. BMC Complementary and Alternative Medicine, 17(1), 1https://doi.org/10.1186/s12906017-1654-y.

Bucholz RW et all. 2006. Fracture In Adults. Phildelphia: lippincott \& Willkins

Clancy, A., \& Svensson, T. (2010). Perceptions of public health nursing consultations: tacit understanding of the importance of relationships. Primary Health Care Research \& Development, 11, 363-373. doi: $10.1017 / \mathrm{S} 1463423610000137$

Depkes RI. 2018. Riset Kesehatan Dasar. Badan Penelitian dan pengembangan Kesehatan Kementrian Kesehatan RI. Jakarta

Didymus, F. F. (2017). Olympic and international level sports coaches, experiences of stressors, appraisals, and coping stressors, appraisals, and coping. Qualitative Research in Sport, Exercise and Health.. https://doi.org/10.1080/2159676 X.2016.1261364

Engel, J., \& Prentice, D. (2013). The ethics of interprofesional collaboration. Nursing Ethics, 20(4), 426-435.

Ideham, S. dkk. 2007. Urang Banjar dan Kebudayaannya. BALITBANGDA KALSEL \& Pustaka Banua. Banjarmasin.

Juwita, E, (Skripsi) 2013. Hubungan Pengetahuan, Pendidikan, Pengalaman, dan Pendapatan 
Ibu Rumah Tangga Dengan Pemanfaatan Obat Tradisional Sebagai Pengobatan Alternatif Di Desa Peunelop kecamatan Labuhan Haji Timur Kabupaten Aceh Selatan, Banda Aceh :FKM Muhammadiah

Lanawati. (2019). Studi Fenomenologi: Pengalaman Psikologis Perempuan Suku Dayak Ma'annyan menjalani adat Ipilah. (Tesis: Tidak dipublikasi)

Martin-Misener, R., Valaitis, R., Wong, S. T., MacDonald, M., MeagherStewart, D., Kaczorowski, J Team, Strengthening Primary Health Care through Public Health and Primary Care Collaborations. (2012). A scoping literature review of collaboration between primary care and public health. Primary Health Care Research \& Development, 13, 327-346. doi: 10.1017/S1463423611000491

Mubarak, W, I \& Chayatin, N (2009). Ilmu Keperawatan Komunitas Pengantar dan Teori. Jakarta : Salemba Medika.

Murthy, R. S. (2016). Role of international collaboration in developing mental health services. Indian Journal of Social Psychiatry, 32(3).

Notosiswoyo., dkk. (2001). Review Penelitian Pengobatan Tradisional Patah Tulang. Jakarta: Media Litbang Kesehatan

Potter,\& Perry AG. (2010). Buku Ajar Fundamental Keperawatan: Konsep, Proses, dan Praktik. 4th ed. EGC: Jakarta.

Prentice, D., Engel, J., Taplay, K., \& Stobbe,

$\mathrm{K}$.

(2015)
Interprofessional collaboration: The experience of nursing and medical students ${ }^{\text {ee }}$ interprofessional education. Global Qualitative Nursing Research, 2, 1-9. doi: $10.1177 / 2333393614560566$

Rasny,H. Susanto, T \& Dewi, E.I (2014). Ethnonursing Penggunaan Terapi Komplementer Pada Suku Using Banyuwangi. Universitas Jember

Sari AP dkk. (2012). Faktor-faktor yang berhubungan dengan keterlambatan berobat pada pasien patah tulang yang menggunakan system pembiayaan jamkesmas. Bandung

Setyoningsih, A \& Artaria, M. D. 2016. Pemilihan Penyembuhan Penyakit Melalui Pengobatan Tradisional Non Medis Atau Medis. Universitas Brawijaya.

Sitomorang, H dkk. 2014: Faktor Faktor Yang Mempengaruhi Kearifan Lokal Pemanfaatan Obat-Obatan Tradisional Oleh Etnik Karo. Prosiding ekspose an tahun 2014 balai penelitiaan kehutanan aek nauli medan, 6 November 2014. ISBN 978-60219559-7-0 hasil penelit https://www.researchgate.net/pr ofile/Alfonso_Harianja/publicati on/

Stuart, G. W. (2016). Prinsip dan Praktik Keperawatan Kesehatan Jiwa Stuart. (B. A. Keliat, Ed.) (Indonesia). Singapore: Elsevier.

Suprapto, Agus (2000). Pengkajian pengobatan patah tulang di pasuruan dan sidoarjo. Sentra pengobatan tradisional 
Susi H.K., dkk. (2010) Faktor-Faktor Yang Melatar Belakangi Pasien Patah Tulang Berobat Ke Pengobatan Tradisional Ahli Tulang Di Sumedang". Fakultas Ilmu Keperawatan Universitas Padjadjaran

Utami, M. N. (2015). Faktor-faktor Pemilihan Pengobatan Tradisional pada Kasus Patah Tulang. 2 (3), 339-342. Retrieved from http://juke.kedokteran.unila.ac.id/i ndex.php/agro/article/view/1371/p df.

Widiarti, A. (2016). Analisis Pengaruh Faktor Perilaku Terhadap Pemanfaatan Kearifan Lokal Sebagai Obat Tradisional Oleh Masyarakat Di Kota Palangka Raya. Jurnal berkala kesehatan https://ppjp.ulm.ac.id/journal/index .php/berkalakesehatan/article/view /4842/4205

World Health Organitation .(2013). WHO Traditional Medicine Strategy 2014-2023, World Health Organitation. Hongkong

Zulkifli. (2014). Pengobatan Tradisional Sebagai Pengobatan Alternatif Harus Dilestarikan. USU 